\title{
Covid-19: Antibody tests will not be rolled out in UK until at least May, MPs hear
}

\author{
Gareth lacobucci
}

The BMJ

Antibody tests to determine whether someone has had covid-19 will not be available until at least May, the government's national testing coordinator has said. John Newton, Public Health England's director of health improvement, said that none of the tests tried so far had been accurate enough.

The government has set itself a target to carry out 100000 covid-19 tests a day by the end of April, through a "five pillar" policy including a big increase in capacity for polymerase chain reaction (PCR) swab tests that detect the presence of the virus, alongside rolling out antibody testing. ${ }^{1}$

But Newton, appointed last week to oversee this increase, told MPs on the House of Commons science and technology select committee on 8 April that he did not expect antibody tests to be factored into this target.

"We do not expect to be doing antibody tests by the end of April," he said. "We're not relying on antibody tests to make up that [100 000] target. A number of companies were offering us these quick antibody tests, and we were hoping that they'd be fit for purpose, but when they got to test, they all worked but were just not good enough to rely on.

"The judgment was made [that] it's worth taking the time to develop a better antibody test before rolling it out, and that is what the current plan is."

\section{Sensitivity}

Newton told the committee that the tests trialled so far had lacked sufficient sensitivity to identify people who had been infected. "We set a clear target for tests to achieve, and none of them frankly were close," he said. "That doesn't mean to say they don't have any value, but we think it is possible to improve on that."

Last month England's health secretary, Matt Hancock, announced that the government had purchased 3.5 million antibody tests, promising to make them available to frontline NHS staff "very soon" so that people could find out whether they had been infected.

But Kathy Hall, director of the covid-19 testing strategy at the Department of Health and Social Care, told the committee that, in light of the trials of the tests, the government would now be "working with companies to cancel the orders and get the money back where possible." She added that "no country has a valid antibody test in use" at present.

But Newton said he was optimistic that a reliable test could emerge soon in the UK, noting comments yesterday ${ }^{2}$ from AstraZeneca's CEO, Pascal Soriot, that an antibody test developed by the company would be ready in May.

Newton said, "There is an active partnership with industry and academics to improve on the underlying molecules that make up the test. We are reasonably optimistic that we can produce a test that does meet the standard in the time when it's needed at very high volumes. But, because it is innovation, we can't be absolutely certain of that."

lacobucci G. Covid-19: government promises 100000 tests per day in England by end of April. BMJ 2020;369:m1392. 10.1136/bmj.m1392 32245880

2 UK coronavirus testing capacity boosted by new AstraZeneca, GSK lab. Reuters 2020 Apr 8. https://www.reuters.com/article/us-health-coronavirus-astrazeneca/uk-coronavirustesting-capacity-boosted-by-new-astrazeneca-gsk-lab-idUSKBN21Q0PR.

Published by the BMJ Publishing Group Limited. For permission to use (where not already granted under a licence) please go to http://group.bmj.com/group/rights-licensing/ permissions 